\title{
ВІДКРИТИЙ УКРАЇНСЬКИЙ ІНДЕКС НАУКОВИХ ЦИТУВАНЬ: МОЖЛИВОСТІ ДЛЯ НАЦІОНАЛЬНОӦ АКАДЕМІЇ ПЕДАГОГІЧНИХ НАУК УКРАЇНИ
}

Доповідь на засіданні Президії НАПН України 14 листопада 2019 р. https://doi.org/10.37472/2707-305X-2019-1-1-6-1

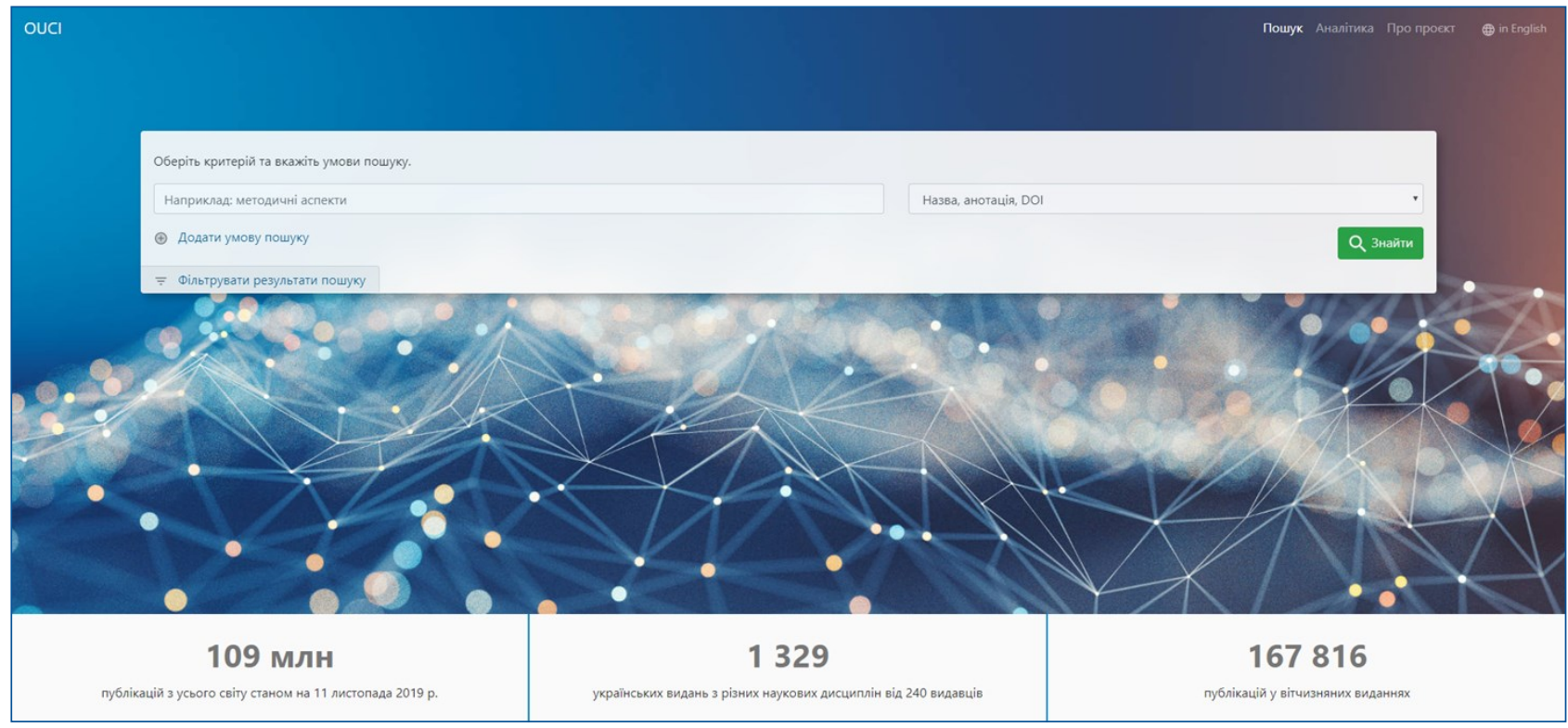

\section{РЕГЕЙЛО Ірина Юріївна}

доктор педагогічних наук, старший науковий співробітник, начальник науковоорганізачійного відділу апарату Президії Національної академії педагогічних наук України, м. Київ, Україна

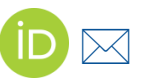

\section{БАЗЕЛЮК Наталія Валеріївна} кандидат педагогічних наук, старший науковий співробітник науково-організаційного відділу апарату Президії Національної академії педагогічних наук України, м. Київ, Україна

Анотація. У Міністерстві освіти і науки України 12 листопада 2019 р. презентовано проєкт Державної науково-технічної бібліотеки України Open Ukrainian Citation Index. Оскільки багато українських вчених, видань та установ залишаються поза межами таких баз, як Scopus ma Web of Science Core Collection, npoєкm надасть змогу відстежувати публікаційну активність та цитованість наукових праць насамперед за соціогуманітарним напрямом. Проєкт використовує відкриті дані з Crossref. Серед підвідомчих установ НАПН України окремі префрікси DOI з Crossref отримали сім інститутів. Підвідомчим установам НАПН України наголошено на необхідності підтримати Ініціативу відкритих цитувань.

Ключові слова: Відкритий український індекс наукових цитувань; Національна академія педагогічних наук України; наукометрична база даних; префікс DOI; Crossref.

12 листопада 2019 р. у Міністерстві освіти і науки України презентовано проєкт Державної науково-технічної бібліотеки України Відкритий український індекс наукових цитувань (Open
Ukrainian Citation Index). Це новий сервіс для пошуку та аналізу наукових цитувань вчених, які надходять від усіх видань, що використовують (Cited-by від) Crossref та підтримують Ініціативу 
відритих цитувань (Initiative for Open Citations) Згідно 3 інформацією першого заступника Міністра освіти і науки України Ю.Ю. Полюховича Відкритий український індекс наукових цитувань $\epsilon$ першою складовою майбутньої Національної науково-інформаційної системи (Ukrainian Research Information System, URIS), створення якої буде одним із пріоритетів МОН України у 2020 р. (МОН України, 2019).

Нині у світі активно розвивається Ініціатива відкритих цитувань, ії схвалюють більшість провідних наукових видавців світу - усього понад 1200 видавців, а також їі підтримують в Україні.

Відкритий український індекс наукових цитувань (OUCI) - це крок України до інтеграції у світову наукову спільноту, оскільки він і побудований на відкритих цитуваннях.

Державна науково-технічна бібліотека України створила аналітичну надбудову на відкритих даних із Crossref, що дає змогу більш зручного доступу до такої інформації та ії аналізу.

Відкритий український індекс наукових цитувань відрізняється тим, що він $€$ повністю некомерційним, доступ до нього безкоштовний та відкритий для всіх. Водночас наповнення бази відбувається за прозорими принципами і вона має зрозумілий механізм захисту від маніпуляцій з цитуваннями.

Оскільки багато українських вчених, видань та установ залишаються поза межами таких баз, як Scopus та Web of Science Core Collection, проєкт надасть змогу відстежувати публікаційну активність та цитованість наукових праць насамперед за соціо-гуманітарним напрямом (MOH України, 2018). За твердженням Ю.Ю. Полюховича «Ні про жодне оцінювання чи прийняття Міністерством рішень на основі даних Відкритого українського індексу наукових цитувань не йдеться» (МОН України, 2019).

Зручний сервіс із пошуку наукових публікацій та аналізу цитувань запускається для науковців, викладачів, студентів, редакцій наукових журналів, представників бізнесу, грантодавців, освітніх та наукових управлінців.

У системі є окремі сторінки установ, періодичних видань, публікацій (функцію пошуку за авторами ще не включено). Передбачено наявність сторінки установи, наукового періодичного видання, окремої наукової публікації, пошуку установи за префіксом тощо.

Звертаємо вашу увагу, що для належної індексації у Відкритому українському індексі наукових цитувань наукових публікацій (монографій, розділів монографій, практичних і методичних посібників, методичних рекомендацій, наукових статей тощо) вчених підвідомчих установ НАПН України та наукових періодичних видань, засновником/співзасновником яких $\epsilon$ установа, необхідно передавати метадані наукових публікацій до Crossref для присвоєння усім науковим публікаціям DOI, ключовим 3-поміж яких $\epsilon$ зазначення ORCID iD авторів та переліків використаних джерел. Система Crossref автоматично встановить зв'язки між елементами, і видавці отримуватимуть дані щодо цитування статей своїх видань.

Серед підвідомчих установ НАПН України окремі префікси DOI отримали сім інститутів (Інститут педагогіки, Інститут педагогічної освіти і освіти дорослих імені Івана Зязюна, Інститут спеціальної педагогіки і психології імені Миколи Ярмаченка, Інститут соціальної та політичної психології, Інститут вищої освіти, Інститут інформаційних технологій і засобів навчання та Інститут професійно-технічної освіти); ще два інститути (Інститут проблем виховання та Інститут обдарованої дитини), Державна науковопедагогічна бібліотека України імені В.О. Сухомлинського та ДзВО «Університет менеджменту освіти» отримують DOI під префіксом Інституту педагогіки НАПН України, а також Інститут психології імені Г.С. Костюка НАПН України має префікси закладів вищої освіти.

Підвідомчим установам НАПН України необхідно підтримати Ініціативу відкритих цитувань, а саме:

1) установам, що приєдналися до Crossref та присвоїли DOI, встановити долучення до Ініціативи відкритих цитувань за відповідним посиланням: https://www.crossref.org/referencedistribution/;

2) установам, що не долучилися до Ініціативи відкритих цитувань, відкрити переліки використаних джерел для усіх розміщених під ї̈ префіксом DOI публікацій. Детальніша інформація міститься у практичному посібнику «Відкритий доступ до наукових цитувань» (Назаровець \& Борисова, 2019).

У разі відсутності DOI, метадані наукових праць не передаються до Crossref та відповідно не будуть відображені в Відкритому українському індексі наукових цитувань. 


\section{СПИСОК ВИКОРИСТАНИХ ДЖЕРЕЛ}

Відкритий український індекс наукових цитувань (Open Ukrainian Citation Index). Взято 3 https:// ouci.dntb.gov.ua/.

Міністерство освіти і науки України (2018). МOH планує запустити відкритий український індекс наукового цитування до кінця року. Взято з https://mon.gov.ua/ ua/news/mon-planuye-zapustiti-vidkritij-ukrayinskijindeks-naukovogo-cituvannya-do-kincya-roku.

Міністерство освіти і науки України (2019). МОН запустило новий пошуковий сервіс для науковців він безкоштовний та базується на відкритих даних 3 усього світу. Взято з https://mon.gov.ua/ua/news/monzapustilo-novij-poshukovij-servis-dlya-naukovciv-vin- bezkoshtovnij-ta-bazuyetsya-na-vidkritih-danih-z-usogosvitu.

Назаровець, С., \& Борисова, Т. (2019). Відкритий доступ до наукових иитувань. Київ: ДНТБ України. https:// doi.org/10.5281/zenodo.2553994.

Назаровець, С. (2019). Проект Open Ukrainian Citation Index (OUCI): ідея, принцип роботи та перспективи розвитку. Інтелектуальна власність в Україні, (3), 10-13.

Cheberkus, D., \& Nazarovets, S. (2019). Ukrainian open index maps local citations. Nature, 575(7784), 596-596. https://doi.org/10.1038/d41586-019-03662-6.

Initiative for Open Citations. Retrieved from https:// i4oc.org/.

\title{
OPEN UKRAINIAN CITATION INDEX: OPPORTUNITIES FOR THE NATIONAL ACADEMY OF EDUCATIONAL SCIENCES OF UKRAINE \\ Report at the Meeting of the Presidium of the National Academy of Educational Sciences of Ukraine, November 14, 2019
}

\author{
Iryna Reheilo \\ DSc in Education, Senior Researcher, Head of the Scientific and Organizational Department, \\ National Academy of Educational Sciences of Ukraine, Kyiv, Ukraine \\ Nataliia Bazeliuk \\ PhD in Education, Senior Research Fellow of the Scientific and Organizational Department, \\ National Academy of Educational Sciences of Ukraine, Kyiv, Ukraine
}

Abstract. The project of the State Scientific and Technical Library of Ukraine Open Ukrainian Citation Index (OUCI) was presented on November 12, 2019 in the Ministry of Education of Science of Ukraine. As many Ukrainian researchers, research journals and research institutions remain outside such databases as Scopus and Web of Science Core Collection, the project will be able to track the publication activity and citations of scientific works primarily in the fields of humanities and social sciences. The OUCl uses open data from Crossref. Among the NAES of Ukraine subordinated institutions seven institutions received separate DOI prefixes. It was emphasized the need to support by the NAES of Ukraine institutions the Initiative for Open Citations.

Keywords: Open Ukrainian Citation Index; National Academy of Educational Sciences of Ukraine; citation index; DOI prefix; Crossref.

Дата публікації: 23 грудня 2019 р. 